\title{
The PNNL Lab Homes Experimental Plan, FY12-FY15
}

SH Widder

GB Parker

MC Baechler

May 2012

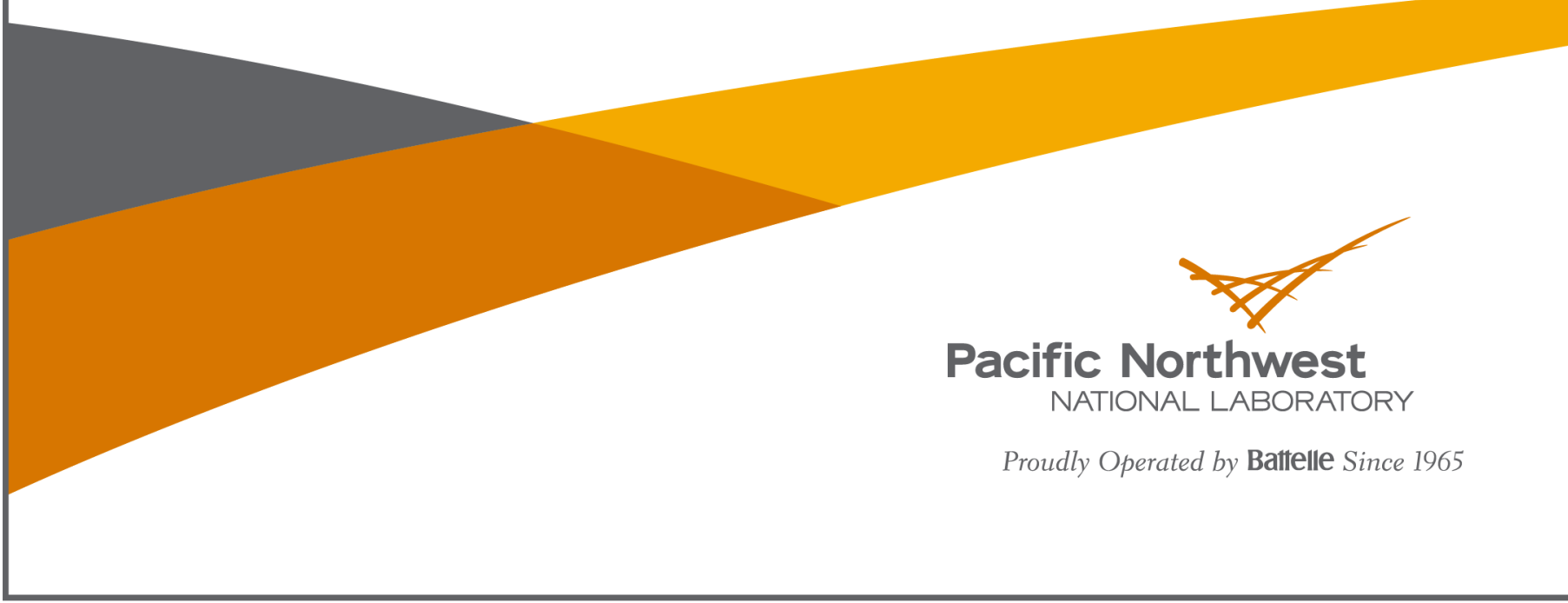




\title{
DISCLAIMER
}

This report was prepared as an account of work sponsored by an agency of the United States Government. Neither the United States Government nor any agency thereof, nor Battelle Memorial Institute, nor any of their employees, makes any warranty, express or implied, or assumes any legal liability or responsibility for the accuracy, completeness, or usefulness of any information, apparatus, product, or process disclosed, or represents that its use would not infringe privately owned rights. Reference herein to any specific commercial product, process, or service by trade name, trademark, manufacturer, or otherwise does not necessarily constitute or imply its endorsement, recommendation, or favoring by the United States Government or any agency thereof, or Battelle Memorial Institute. The views and opinions of authors expressed herein do not necessarily state or reflect those of the United States Government or any agency thereof.

\author{
PACIFIC NORTHWEST NATIONAL LABORATORY \\ operated by \\ BATTELLE \\ for the \\ UNITED STATES DEPARTMENT OF ENERGY \\ under Contract DE-AC05-76RL01830
}

Printed in the United States of America
Available to DOE and DOE contractors from the Office of Scientific and Technical Information, P.O. Box 62, Oak Ridge, TN 37831-0062; ph: (865) 576-8401 fax: $(865) 576-5728$
email: reports $a$ adonis.osti.gov
Available to the public from the National Technical Information Service 5301 Shawnee Rd., Alexandria, VA 22312 ph: (800) 553-NTIS (6847)

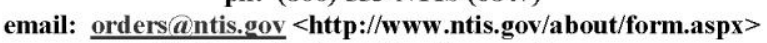 Online ordering: http://www.ntis.gov




\section{The PNNL Lab Homes Experimental Plan, FY12-FY15}

SH Widder

GB Parker

MC Baechler

May 2012

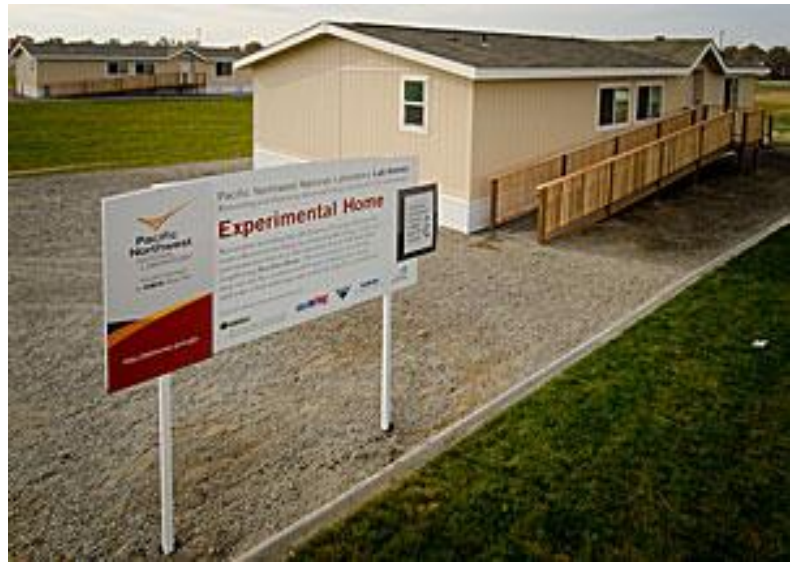

Prepared for

the U.S. Department of Energy

under Contract DE-AC05-76RL01830

Pacific Northwest National Laboratory

Richland, Washington 99352 



\section{Summary}

Retrofitting and renovating existing homes to save energy has become an increasingly important component of the Nation's energy strategy. Recognizing the need to aggressively research and develop deep energy retrofit strategies for existing homes, the U.S. Department of Energy (DOE) is pursuing many innovative and impactful projects as part of its Building America (BA) program. One of these projects is providing partial support for two factory-built Lab Homes recently installed on the Pacific Northwest National Laboratory (PNNL) campus in Richland, Washington, which allow for the validation, demonstration, and characterization of new, energy efficient and peak load shaving technologies. The experimental home is retrofit with an energy- or water-efficient or smart technology to demonstrate the performance of that technology, while the baseline home serves as the control for side-by-side comparison of performance in homes with and without the retrofit measure under identical occupancy rates and weather conditions. Together, they serve as a research platform for testing and comparing new ideas and approaches that are applicable to site-built and manufactured homes. As the Lab Homes steward, PNNL works with multiple clients and stakeholders to use the Lab Homes for experiments focused on reducing energy use, improving grid responsiveness, and shaving peak demand.

This Experimental Plan builds on the results of a stakeholder workshop that identified the types of research experiments to be conducted and possible funding sources and partners. As a general guideline, this plan proposes a series of sometimes overlapping of experiments to be conducted within each fiscal year (FY) from FY 2012 through FY 2015. The experiments are designed to derive results that will help define effective retrofit solution packages in moderate and cold climates that can be cost-effectively deployed in the Pacific Northwest or other climate zones to reduce the energy consumption of a typical home by $50 \%$, while also enhancing the home's health, comfort, and durability. This plan is also intended to leverage the unique opportunity offered by the Lab Homes to collaborate with multiple research partners on new, smart, and efficient solutions for residential retrofits, as well as increase PNNL's visibility in the energy-efficient buildings research area by communicating the unique and impactful data derived from experiments conducted in the Lab Homes.

The plan serves as a preliminary proposal that may be amended to reflect the emergence of new technologies, incorporate new experiments, address the needs of new research partners, and the availability of funding. A flexible experimental plan and schedule is intended to enable the Lab Homes to serve as an open platform for demonstrating, evaluating, and developing new, innovative energy-efficient and grid-smart technologies that meet all partner goals. 



\section{Acronyms and Abbreviations}

\begin{tabular}{|c|c|}
\hline BA & Building America \\
\hline BPA & Bonneville Power Administration \\
\hline BTP & Building Technologies Program \\
\hline CRADA & Cooperative Research and Development Agreement \\
\hline $\mathrm{CY}$ & calendar year \\
\hline DHW & domestic hot water \\
\hline DOE & U.S. Department of Energy \\
\hline EPRI & Electric Power Research Institute \\
\hline EV & electric vehicle \\
\hline $\mathrm{ft}^{2}$ & square (foot)feet \\
\hline FY & fiscal year \\
\hline GE & General Electric \\
\hline GSHP & ground-source heat pump \\
\hline HEM & home energy management \\
\hline HP & heat hump \\
\hline HРMH & High-Performance Manufactured Home \\
\hline HPWH & heat pump water heater \\
\hline HUD & U.S. Department of Housing and Urban Development \\
\hline HVAC & heating, ventilation, and air conditioning \\
\hline $\mathrm{K}$ & thousand \\
\hline $\mathrm{kWh}$ & kilowatt-hour(s) \\
\hline PNNL & Pacific Northwest National Laboratory \\
\hline $\mathrm{MH}$ & manufactured home \\
\hline NEEA & Northwest Energy Efficiency Alliance \\
\hline NEEM & Northwest Energy Efficiency Manufactured Home \\
\hline NEW & Northwest Energy Works \\
\hline NILM & non-intrusive load monitoring \\
\hline NIST & National Institute of Standards and Technology \\
\hline $\mathrm{OE}$ & Office of Electricity \\
\hline PCM & phase change material \\
\hline PV & photovoltaic \\
\hline $\mathrm{R} \& \mathrm{D}$ & research and development \\
\hline SSL & solid-state lighting \\
\hline WSU & Washington State University \\
\hline
\end{tabular}





\section{Contents}

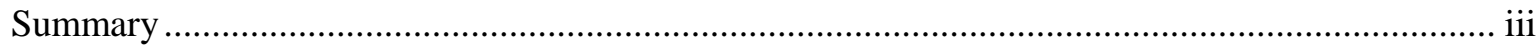

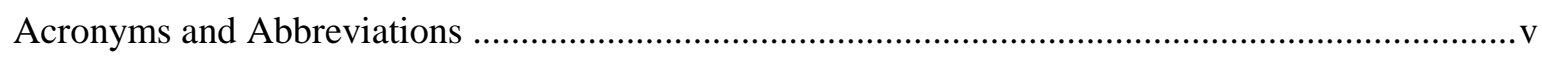

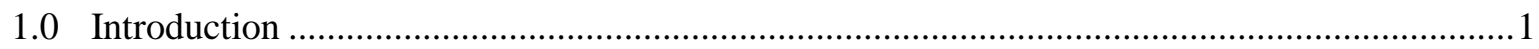

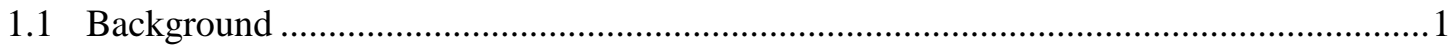

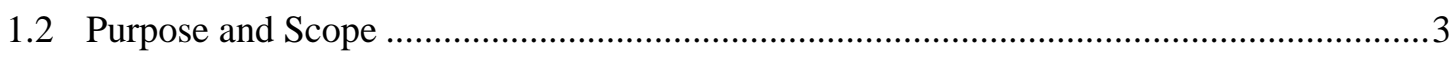

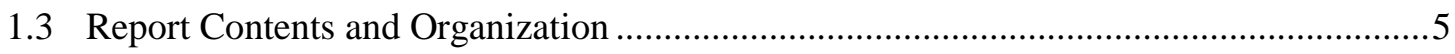

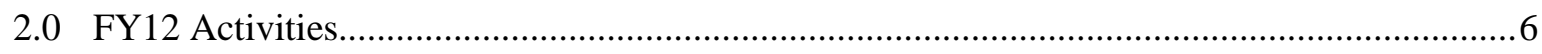

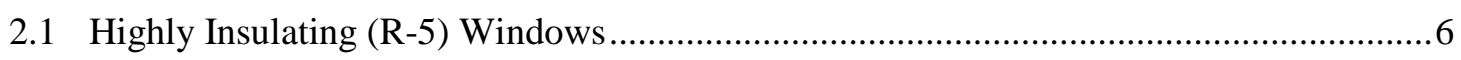

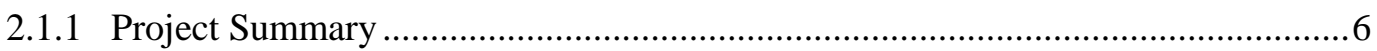

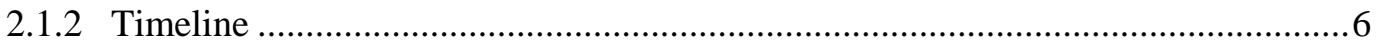

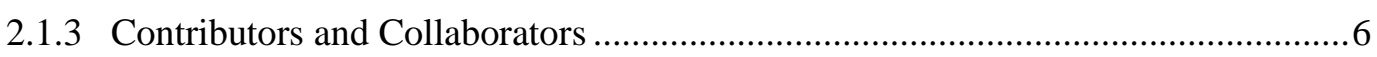

2.2 Smart Grid Appliances/EV Charging Station .......................................................

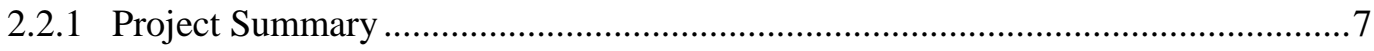

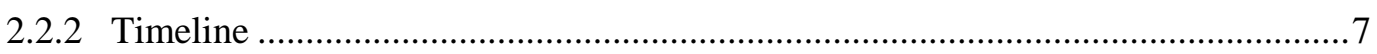

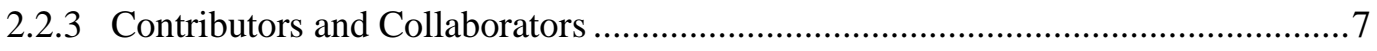

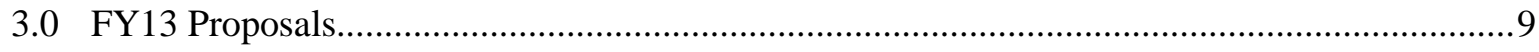

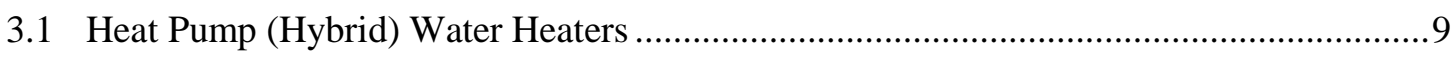

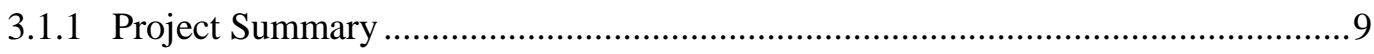

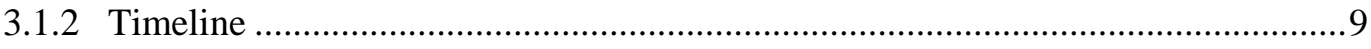

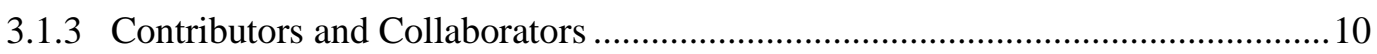

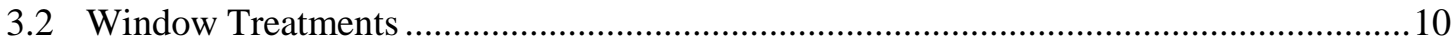

3.2.1 Project Summary .................................................................................... 10

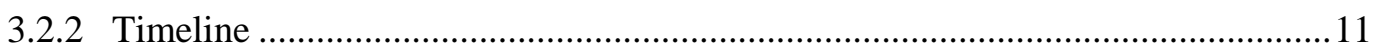

3.2.3 Potential Contributors and Collaborators ......................................................... 12

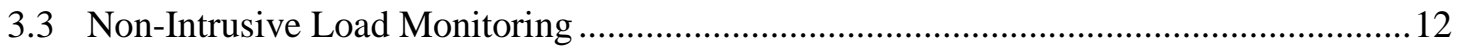

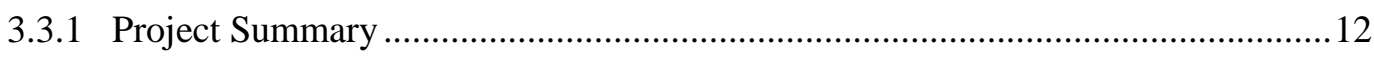

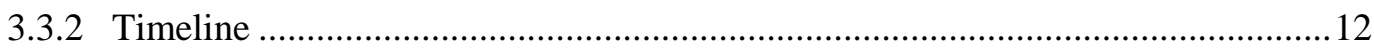

3.3.3 Potential Contributors and Collaborators .......................................................... 12

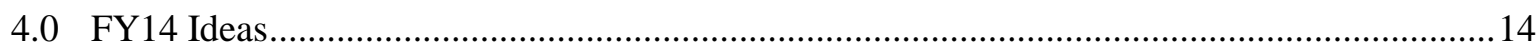

4.1 Manufactured Housing Ventilation Effectiveness.......................................................... 14

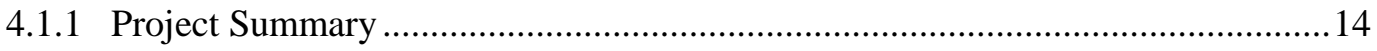

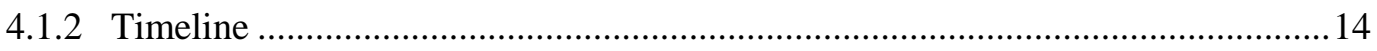

4.1.3 Potential Contributors and Collaborators ….................................................... 14

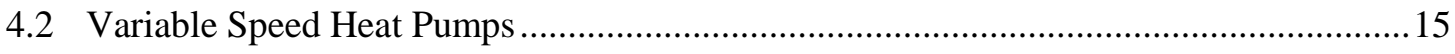

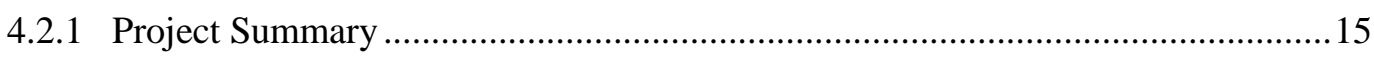

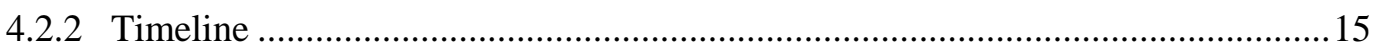




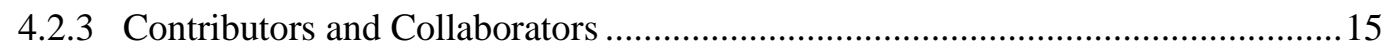

4.3 Integrated Water and Space Heating Mini-Split Heat Pumps ....................................... 16

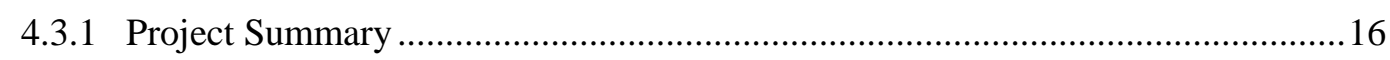

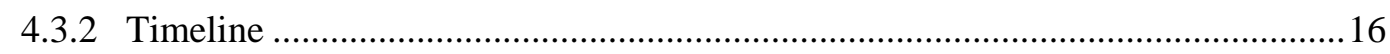

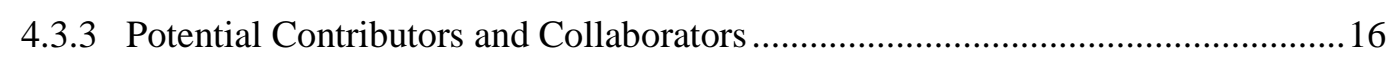

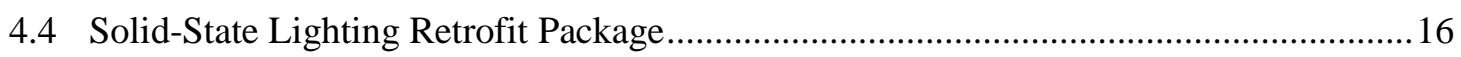

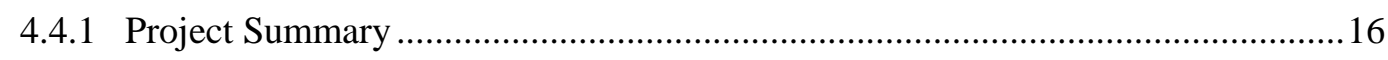

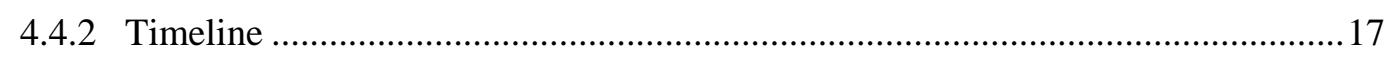

4.4.3 Potential Contributors and Collaborators ........................................................... 17

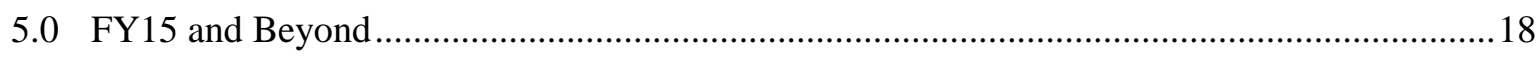

5.1 PV Interaction with Smart-Grid Enabled Appliances and EV Charging .........................18

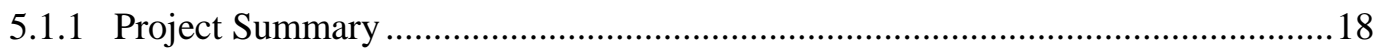

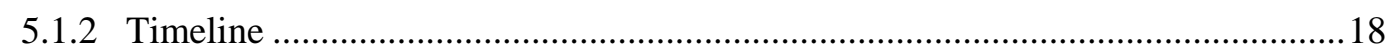

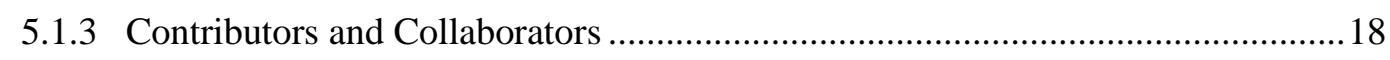

5.2 PCMs and Insulation Installation Best Practices......................................................... 19

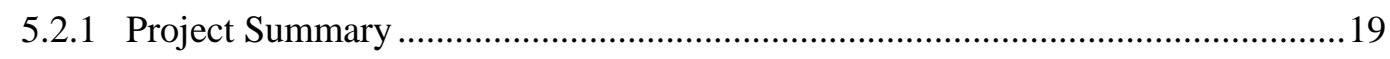

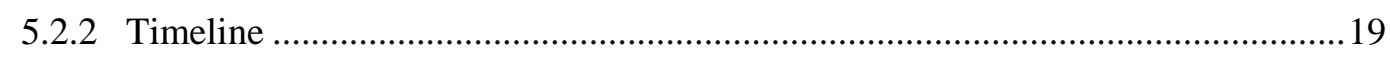

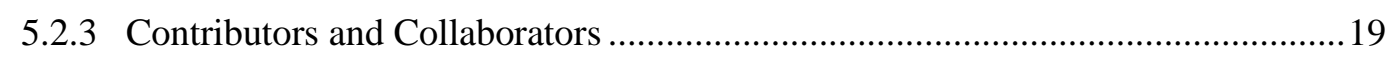

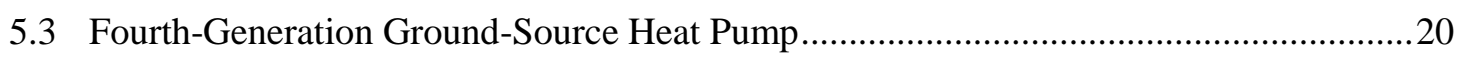

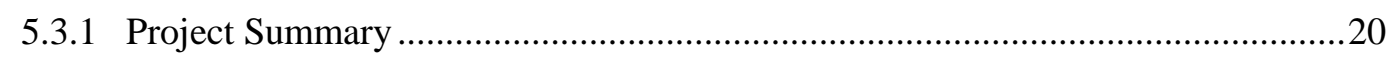

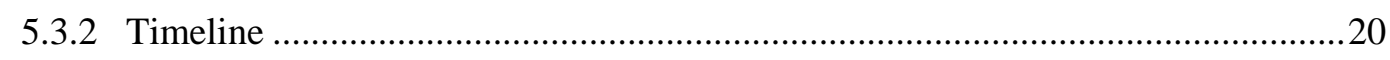

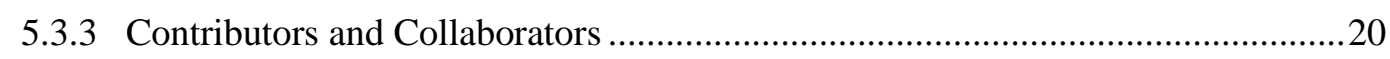

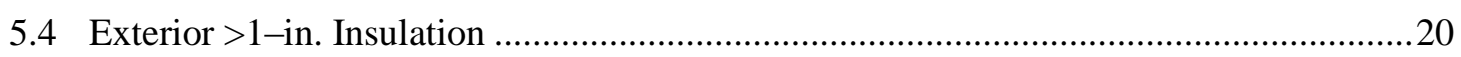

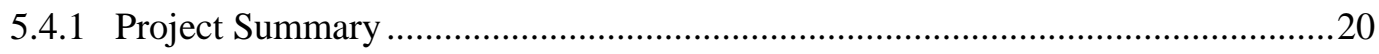

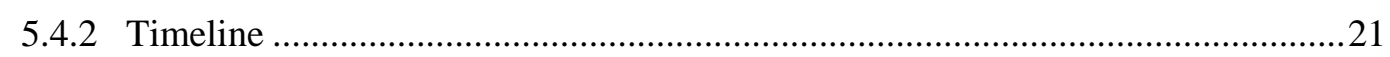

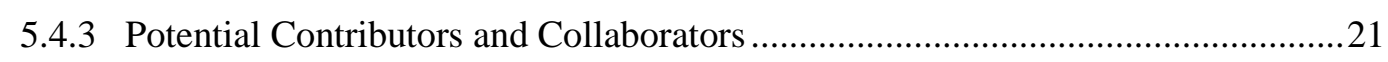

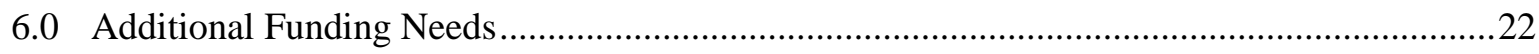

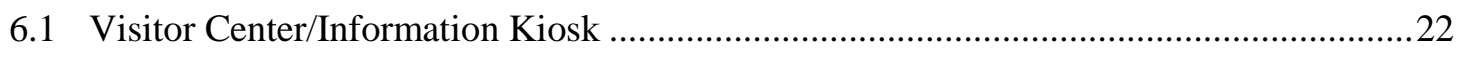

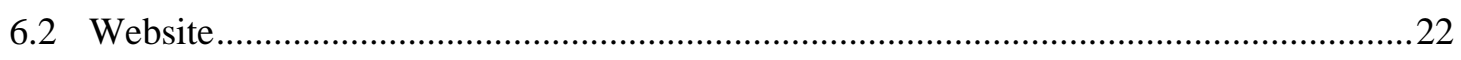

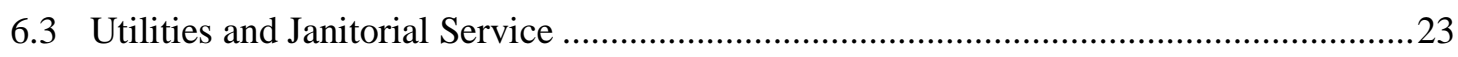

Appendix A - PNNL Lab Homes Stakeholder Workshop Notes ..................................................1

Appendix B - Proposed Experimental Schedule for the PNNL Lab Homes ................................ B.1 


\section{Tables}

Table 1. Important Events and Experimental Schedule for FY12 …....................................6

Table 2. Programs and Financial Contributions of Participating Research Partners for the

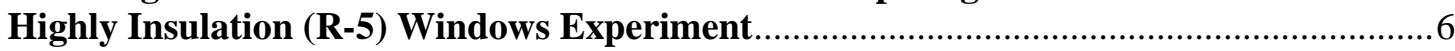

Table 3. Programs and Financial Contributions of Participating Research Partners for the Smart Grid Appliance/EV Charging Station Experiments......................................... 8

Table 4. Proposed Experimental Schedule for FY13 .........................................................

Table 6. Programs and Financial Contributions of Potential Research Partners for the Heat Pump (Hybrid) Water Heater Experiment ....................................................... 10

Table 7. Programs and Financial Contributions of Potential Research Partners for the Non-Intrusive Load Monitoring Experiment ..................................................................... 13

Table 8. Proposed Experimental Schedule for FY14 …......................................................... 14

Table 5. Programs and Financial Contributions of Potential Research Partners for the Manufactured Housing Ventilation Effectiveness Experiment ....................................... 15

Table 9. Proposed Experimental Schedule for FY 15 …................................................... 18 


\subsection{Introduction}

The residential buildings sector uses approximately $23 \%$ of primary energy (energy that exists in a naturally occurring form, such as coal, before being converted into an end-use form) and $36 \%$ of electricity generated in the United States. As new home construction rates decrease while the market struggles to recover from the recession, retrofitting and renovating our existing homes to save energy becomes increasingly important. Consequently, the U.S. Department of Energy (DOE) has recognized the need to aggressively research and develop deep energy retrofit strategies as part of the Building America (BA) program (http://www1.eere.energy.gov/buildings/building_america/). The Pacific Northwest National Laboratory (PNNL) has several projects funded by the BA program including partial funding for the two PNNL Lab Homes.

\subsection{Background}

The PNNL Lab Homes (http://labhomes.pnnl.gov/) comprise two factory-built homes recently installed on PNNL's campus in Richland, Washington. The Lab Homes serve as a research platform for DOE, PNNL, and other research partners who aim to test potential energy- and water-efficient and gridresponsive technologies in homes. The PNNL Lab Homes project is the first of its kind in the Pacific Northwest region and one of only a few that exist in the United States. The unique capability of the Lab Homes lies in the function of each home: one home (the experimental home or Lab Home B) is retrofit with an energy- or water-efficient or smart technology to demonstrate the performance of that technology, while the other home (the baseline home or Lab Home A) serves as the control, continuing to exhibit the performance of a similar unretrofit home under identical occupancy scenarios and weather conditions.

PNNL is the steward of the Lab Homes and is working with multiple clients and stakeholders to use the pair of identical, electrically heated, $1,500-\mathrm{ft}^{2}$ homes for experiments focused on reducing energy use, improving grid responsiveness, and shaving peak demand. Research and demonstration primarily will focus on the assessment and analysis of retrofit technologies, and the homes will offer a unique, side-byside ability to test and compare new ideas and approaches that are applicable to site-built and manufactured homes. The siting and instrumentation of the Lab Homes was made possible by contributions from many stakeholders, which illustrates the broad interest and significant potential for collaboration and synergism inherent in the Lab Homes. In fiscal year 2011-2012 (FY11/12) a total of $\$ 1,030 \mathrm{~K}$ was invested for planning, engineering, procurement, and siting of the homes, and for undertaking the initial experiments in FY12. Dollar investments by partner were as follows:

- DOE/Building Technologies Program (BTP)/Building America-American Recovery and Reinvestment Act $(\$ 600 \mathrm{~K})$

- DOE/BTP/Building America (\$100K)

- DOE/BTP/Windows and Envelope Research and Development (R\&D) (\$160K)

- Bonneville Power Administration (\$90K)

- DOE/Office of Electricity Delivery and Energy Reliability (OE) (\$130K)

- PNNL Facilities and Operations (\$88K)

- Tri Cities Research District (\$7K) 
- City of Richland (\$5K)

- Battelle Memorial Institute (land)

- General Electric (GE) Appliances (in kind under a Cooperative Research and Development Agreement [CRADA]).

The ribbon-cutting ceremony for the Lab Homes occurred on November 15, 2011. That afternoon, a stakeholder workshop was conducted that allowed researchers to discuss the types of research experiments that should be conducted starting in FY13 and to identify possible funding sources and partners. A summary of the outcomes from the stakeholder workshop is attached in Appendix A. With this information, and based on additional discussions with stakeholders from the Bonneville Power Administration (BPA), the Northwest Energy Efficiency Alliance (NEEA), the City of Richland, Northwest Energy Works (NEW), the Washington State University (WSU) Extension Energy Program, as well as manufacturers and national stakeholders, the PNNL team has concluded that research in several areas is required to achieve energy savings of $50 \%$ in existing homes while maintaining or improving the health, comfort, and durability of the homes. Thorough analysis of the following technologies and measures can lead to the determination of their cost effectiveness and their contribution to achieving 50\% energy savings and peak load reduction in homes:

- Building Enclosure

- Impact of highly insulating (R-5) windows and interior/exterior window treatments

- New and emerging techniques for insulating poorly or partially insulated wall cavities

- Assessment of the use of phase-change materials (PCMs) as insulation

- Strategies for cost-effectively achieving greater than 1-in. exterior foam insulation

- Heating, Ventilation, and Air Conditioning (HVAC)

- Impact of variable speed, inverter-driven heat pump (HP) on energy consumption and ventilation effectiveness

- Next generation of retrofit ground-source HP technology

- Effectiveness of whole-house ventilation methods for manufactured housing (MH)

- Domestic Hot Water (DHW) and Hybrid Systems

- Performance and building energy impact of ducted versus unducted heat pump water heaters (HPWHs) located in a conditioned space

- Smart-grid enabled/ducted HPWH demand response characteristics

- Hybrid mini-split HPs with indoor space conditioning and water heating components

- Appliances, Lighting, and other Equipment

- Peak load reduction and demand response from energy-efficient, smart-grid enabled appliances and smart electric vehicle (EV) charging

- Energy saving potential of interior and exterior solid-state lighting (SSL) packages

- Other Technologies 
- $\quad$ Non-intrusive load monitoring (NILM) devices

- Rooftop photovoltaic (PV)/smart micro-inverter

- Home energy management (HEM) systems.

\subsection{Purpose and Scope}

The Lab Homes experimental plan has several objectives, as follows:

- Define effective retrofit solution packages in moderate and cold climates that can be cost-effectively deployed in the Pacific Northwest to reduce the energy consumption of a typical home by $50 \%$, while enhancing the home's health, comfort, and durability. Evaluate the defined retrofit strategies for their ability to lower peak power demand. Ensure that the packages are transportable to other climate zones and regions of the country and applicable to energy-efficient new housing designs as well.

- Leverage the unique opportunity offered by the Lab Homes to reach out to researchers, industry, and other interested parties in the building science community to collaborate on new, smart, and efficient solutions for residential retrofits.

- Increase PNNL's visibility in the energy-efficient buildings research area by communicating the unique and impactful data generated by experiments conducted in the Lab Homes.

This document describes a proposed experimental plan for the Lab Homes to achieve these goals, through FY15, for planning purposes. As this is not a formal or final schedule, this document is for limited distribution only. The research team expects the Lab Homes to house experiments and produce meaningful, significant results well beyond FY15, but given the dynamic nature of building science research it is difficult to accurately predict what experiments will be timely and of most importance at that time. Thus, this document relies on the planning time horizon of FY12-FY15. It is expected that this experimental plan will be amended or subsequent research plans will be created to continually plan for future experiments past FY15, as appropriate.

In addition to identifying funding requirements for conducting technical experiments, it is important that the Lab Homes experimental plan identify the resources required to share information and increase the visibility of the Lab Homes project, including developing and maintaining an interactive website and other outreach efforts. These efforts could include making the monitored data from the Lab Homes publicly available in a clear and consistent format, which will allow other researchers to perform additional, more in-depth analyses. Also, project budgets must include general maintenance tasks, such as janitorial services and utilities.

Due to annual funding cycles and the necessity for diurnal experiments for many of the proposed technology experiments, it is difficult to pursue more than one "irreversible" or "seasonal" experiment at a time. Being conscious of experimental data integrity and overlap, the following timeline summary is proposed for research and demonstrations conducted from FY12 through FY15:

- FY12

- Highly insulating (R-5) windows (winter and summer)

- Smart grid enabled appliances (late summer/early fall)

- FY13 
- Smart grid enabled appliances interoperability with EV charging (fall and spring)

- Ducted, smart grid enabled HPWH (winter and summer)

- NILM (anytime, provided all major loads are captured)

- Window treatments - Low-e storms (winter and late summer)

- Window treatments - Other, such as insulated shades, Low-e coatings, exterior shading, and polychromic films (late summer)

- FY14

- $\mathrm{MH}$ ventilation effectiveness (fall)

- Variable speed HP (early winter and summer)

- Integrated water and space heating mini-split heat pump (late winter and summer)

- SSL package (spring)

- FY15/Other ideas

- Building integrated PV/smart inverter: interaction with smart grid appliances and EV charging (early fall)

- PCMs/insulation installation (winter and early summer)

- Next-generation ground-source HP (late winter and summer)

- Exterior insulation retrofit (fall and winter into FY16).

A detailed schedule of the proposed experiments is provided in Appendix B.

The PNNL research team acknowledges that this plan serves as a guideline for pursuing and scheduling research activities and experiments in the Lab Homes, and additional ideas and opportunities will arise that may change the timing or scope of research and experiments undertaken in the homes. Thus, planning for the Lab Homes must be flexible. This plan serves as a starting place for discussion of research ideas and opportunities that will be continually revised as new technology emerges, new experiments are proposed, new research partners are identified, and as funding becomes available. Using a flexible schedule allows the Lab Homes to serve as an open platform for demonstrating, evaluating, and developing new, innovative energy-efficient and grid-smart technologies that meet all partner goals. As experiments occur further out in time, the specific proposals and expected funding amounts become less precise because they have not yet been fully vetted.

By leveraging other residential buildings R\&D programs — such as the Northwest test bed homes, BPA and NEEA residential research programs, and the Energy Trust of Oregon residential technology demonstrations - the detailed data derived from experiments conducted in the Lab Homes can be transferred and applied to homes across the country, which will both verify savings estimates for occupied homes and achieve greater market penetration and energy-savings impact of proven technologies. Data derived from the Lab Homes research can be used to create savings estimates and performance models in other climates using detailed and precise EnergyPlus models that have been verified using monitored data. 


\subsection{Report Contents and Organization}

The ensuing sections of this plan describe experiments that are underway in the Lab Homes or will be started this year (Section 2.0). Proposed activities are then described separately for FYs 2013, 2014, and 2015 in Sections 3.0 through 5.0. These sections provide brief descriptions of each proposed experiment, summarize the timing of the experiments (including any experiments that may be run in parallel), and propose potential contributors and collaborators. If available, funding information for the experiments is provided. Section 6.0 on additional funding needs describes maintenance costs and ideas for helping to communicate research findings from Lab Home experiments. Appendix A includes notes that contain ideas generated during the stakeholder meeting for the Lab Homes held in November 2011. Appendix B contains a complete draft matrix prepared for DOE that summarizes all of PNNL's research related to new and existing homes for the BA program. 


\subsection{FY12 Activities}

This section describes experiments which are being conducted as part of the FY12 research agenda. These include investigation of the performance and comfort impacts of highly insulating (R-5) windows and the demand response characteristics of a suite of smart-grid enabled appliances. The following table provides a schedule of important events and the experiments occurring in FY12.

Table 1. Important Events and Experimental Schedule for FY12

\begin{tabular}{|c|c|c|c|c|c|c|c|c|c|c|c|c|}
\hline Month & Oct-11 & Nov-11 & Dec-11 & Jan-12 & Feb-12 & Mar-12 & Apr-12 & May-12 & Jun-12 & Jul-12 & Aug-12 & Sep-12 \\
\hline \multicolumn{13}{|l|}{ Ribbon Cutting } \\
\hline \multicolumn{13}{|l|}{ Meter Installation } \\
\hline \multicolumn{13}{|l|}{ Null Testing } \\
\hline \multicolumn{13}{|l|}{ R-5 Windows } \\
\hline $\begin{array}{l}\text { Smart-Grid Enabled } \\
\text { Appliances }\end{array}$ & & & & & & & & & & & & \\
\hline
\end{tabular}

\subsection{Highly Insulating (R-5) Windows}

\subsubsection{Project Summary}

In FY12, PNNL is examining the performance of highly insulating (R-5) windows in heating and cooling seasons. The research project will evaluate the energy-savings potential and thermal comfort impacts of triple-pane, argon/krypton-filled, double Low-e-coated windows with vinyl frames (highly insulating) to double-pane, clear glass windows with aluminum frames, which typify windows in existing homes in the Pacific Northwest and across much of the country. Calibrated thermal models from the Lab Homes experiment will be used to extrapolate data to different climate zones.

\subsubsection{Timeline}

The Lab Homes were retrofit with high-performance (R-5) windows in the experimental home and aluminum double-pane clear glass windows in the baseline home in the winter of 2011-2012. The heating season data collection terminated on April 13, 2012, and preliminary results will be reported to BPA and DOE/BTP-Windows R\&D clients. Other stakeholders will also receive the final report. The cooling season characterization of the R-5 windows will occur in July and August 2012. Results for the cooling season will be reported to DOE's BA program, and shared with other stakeholders, in August.

\subsubsection{Contributors and Collaborators}

For the R-5 windows experiment, funding and in-kind support is provided by the entities listed in table 2:

Table 2. Programs and Financial Contributions of Participating Research Partners for the Highly Insulation (R-5) Windows Experiment

\begin{tabular}{ll}
\hline Entity & Amount \\
\hline DOE BTP - BA & \$100K (cooling season experiment) \\
DOE BTP - Windows R\&D & $\$ 160 \mathrm{~K}$ (heating season experiment) \\
\hline
\end{tabular}




\begin{tabular}{ll}
\hline BPA & \$90K (heating season experiment) \\
Jeld-Wen, Inc. & Technical assistance and materials for installation of \\
& R-5 windows (in-kind) \\
Northwest Energy Works (NEW) & Ventilation/HVAC system testing (in-kind) \\
WSU-Extension Energy Program & IR photos and ventilation/HVAC system testing (in-kind) \\
\hline
\end{tabular}

\subsection{Smart Grid Appliances/EV Charging Station}

\subsubsection{Project Summary}

This project will explore the interoperability and interaction of multiple smart-grid enabled appliances manufactured by GE Appliances. The appliances to be installed and assessed in the experimental Lab Home include a dishwasher, HPWH, refrigerator, washer, dryer, and range. The baseline Lab Home will be equipped with typical, minimum-efficiency appliances that do not respond to price signals to serve as a control for the smart appliances installed in the experimental home. The appliances will be sent artificial price signals through the GE Nucleus Energy Manager (a smart-grid enabled communication device) to assess and analyze the combined demand-response capability of the suite of smart appliances that have been modeled by PNNL in GRIDLabD. ${ }^{1}$ Because the smart-grid enabled appliances also represent ENERGY STAR efficiency levels, the energy savings and load-reduction potential of improvements in appliance efficiency will also be determined. The impact of the smart, efficient appliances on peak load will be characterized using simulated occupancy in the homes.

In the next phase of this experiment (FY13), the interoperability of the suite of smart grid appliances and an EV charging station will be explored. Also, the communications protocols and the additional impacts on load balancing introduced by the EV charging across several price signals will be documented.

\subsubsection{Timeline}

In the spring of 2012, the smart grid and baseline appliances will be installed in the Lab Homes and the energy consumption and operational characteristics of the appliances will be tested and documented. Characterization of smart grid appliance interaction and impact when a demand event (via a price signal) occurs will begin in September 2012 and continue into October/November 2012. This experiment will overlap with the ventilation experiments (see Section 3.3 and Appendix B).

In early FY13, an EV charging station will be installed. Communications protocols and their impacts on the load balancing and energy management of the smart grid appliances and EV charging will be examined. The experiment will conclude in April 2013. There is potential to continue this research in out-years by adding the interaction of renewable energy sources, most likely building-integrated photovoltaics, to the above experiment. See FY15 ideas (Section 5.0) for details.

\subsubsection{Contributors and Collaborators}

For the initial smart-grid appliance experiments, funding is provided by the entities listed in Table 3.

\footnotetext{
${ }^{1}$ http://gridlabd/
} 
Table 3. Programs and Financial Contributions of Participating Research Partners for the Smart Grid Appliance/EV Charging Station Experiments

\begin{tabular}{ll}
\hline Entity & Amount \\
\hline DOE Office of Electricity & $\$ 130 \mathrm{~K}$ \\
GE Appliances & CRADA to supply smart-grid enabled appliances, including \\
& GE's Nucleus Energy Manager (communication device) \\
\hline
\end{tabular}




\subsection{FY13 Proposals}

This section describes experiments which are proposed to occur in FY13. These include investigation of the demand response characteristics of a suite of smart-grid enabled appliances integrated with EV charging; the performance and demand response characteristics of ducted HPWHs; peak load, and comfort impacts of Low-e storms and other window treatments; and the accuracy of non-intrusive load metering. The following table provides a schedule of the experiments proposed to occur in FY13.

Table 4. Proposed Experimental Schedule for FY13

\begin{tabular}{|c|c|c|c|c|c|c|c|c|c|c|c|c|}
\hline Month & Oct-12 & Nov-12 & Dec-12 & Jan-13 & Feb-13 & Mar-13 & Apr-13 & May-13 & Jun-13 & Jul-13 & Aug-13 & Sep-13 \\
\hline \multicolumn{13}{|c|}{$\begin{array}{l}\text { Smart-Grid Enabled } \\
\text { Appliances }\end{array}$} \\
\hline \multicolumn{13}{|c|}{ Ducted HPWH } \\
\hline \multicolumn{13}{|c|}{ Low-E Storm Windows } \\
\hline NILM & & & & & & & & & & & & \\
\hline
\end{tabular}

\subsection{Heat Pump (Hybrid) Water Heaters}

\subsubsection{Project Summary}

BPA and GE Appliances are interested in partnering with PNNL in jointly funded research to evaluate the second-generation GeoSpring ${ }^{\text {TM }}$ GE Hybrid Heat Pump Water Heater (GeoSpring ${ }^{\text {TM }}$ HPWH) in the Lab Homes in controlled experiments. Current laboratory and field research by NEEA and BPA/Electric Power Research Institute (EPRI) includes first-generation GeoSpring ${ }^{\mathrm{TM}}$ HPWHs in both ducted (exhaust air) and unducted configurations. The Lab Home testing will fill a gap in the market transformation of HPWH by providing a controlled setting in which to better understand and validate laboratory models used to evaluate home heating/cooling impacts when HPWHs are installed in conditioned spaces in cold climates. An HPWH with a cold-air exhaust duct to the outside will affect the air-exchange rates and the heating requirements of the home. The unit's source of supply air can also cause infiltration and affect total HVAC loads and HPWH performance. This interaction will also be explored by comparing the performance of a unit with ambient indoor supply air (typical configuration) to a unit that has been modified to provide supply air from the semi-conditioned crawlspace. This experiment will be conducted in partnership with NEW, which is interested in using the results in the development of new specifications for High-Performance Manufactured Homes (HPMHs) in the Pacific Northwest that go beyond the current Northwest Energy Efficiency Manufactured Home (NEEM) specifications. ${ }^{2}$ The demand response characteristics and integration of this (updated) smart-grid-enabled HPWH (along with other smart-grid enabled appliances) will be also included in the project demonstration.

\subsubsection{Timeline}

If this proposed project is funded, the HPWHs would be installed in the fall of 2012 with experiments beginning in the winter (heating season). The heating season experiment would begin with the installation of an unducted HPWH in the experimental home, which would be compared to the

\footnotetext{
${ }^{2}$ http://www.nwcouncil.org/energy/rtf/meetings/2012/04/Industry\%20Spec\%20memo.pdf
} 
performance of the existing electric resistance hot-water heater in the baseline home. An unducted HPWH would then be installed in the baseline home, and the HPWH in the experimental home would be modified to include exhaust air ducting. The ducted HPWH would then be compared to the unducted unit in the baseline home. These energy and thermal performance experiments would be conducted from November 2012 through January 2013. The evaluation of the demand-response capability of the HPWHs and their interoperability with the smart grid appliance suite would take place in the February-April 2013 time frame. The cooling season impacts of ducted and unducted HPWHs would be examined in May through July 2013.

\subsubsection{Contributors and Collaborators}

This proposed project may include joint funding provided by the entities listed in Table 6 .

Table 5. Programs and Financial Contributions of Potential Research Partners for the Heat Pump (Hybrid) Water Heater Experiment

\begin{tabular}{ll}
\hline Entity & Amount (estimate) \\
\hline DOE BTP-BA & $\$ 40 \mathrm{~K}$ \\
DOE OE & $\$ 35 \mathrm{~K}$ ( to evaluate demand response) \\
GE Appliances & $\begin{array}{l}\text { Provide } 2 \text { second generation GeoSpring }{ }^{\mathrm{TM}} \text { Hybrid Water Heaters } \\
\text { and engineering design assistance for ducting }(\sim 30 \mathrm{~K})\end{array}$ \\
BPA & $\$ 96 \mathrm{~K}$ \\
NEW & In-kind, labor $(\sim \$ 10 \mathrm{~K})$ \\
\hline
\end{tabular}

\subsection{Window Treatments}

\subsubsection{Project Summary}

Due to the potential for significant savings with a relatively low installed cost, there has been increasing interest in the energy-savings potential and comfort impacts of window coverings, window films, storm windows, and other window treatments that can decrease the solar heat gain and/or increase the thermal resistance of existing windows ${ }^{3}$. This project would explore the heating season and cooling season improvements in energy savings and comfort derived from Low-E storm windows to create a robust data set to verify savings estimates and support market deployment of the technology. Various other, relatively low-cost and easy-to-retrofit window treatments, may be examined as a comparison as time allows or as part of future work. These technologies could include the following:

- Low-e storm windows (interior or exterior)

- Low-e window films

- passive solar shades

- polychromic film

- others, depending on current research interest.

\footnotetext{
${ }^{3}$ http://www.energyboom.com/efficiency/window-film-energy-savings-superhero; http://www.washingtontimes.com/news/2012/feb/9/cover-story-window-treatments-combine-energy-effic/;
} 
Previous work on the energy impacts of window treatments includes research at the Canadian Centre for Housing Technology Twin Research Homes, examining passive and active solar shades, Low-e window glazings, reflective shading, blind placement, and blind control. ${ }^{4}$ Housing and Urban Development (HUD) also sponsored a field evaluation of low-E storm windows in Chicago. ${ }^{5}$ Other work has been conducted by manufacturers of the products, ${ }^{6}$ but unbiased third-party evaluation and comparison are needed to inform utility and governmental programs, as well as consumer choices. In addition, the National Fenestration Rating Council (NFRC) created an Attachment Subcommittee in 2008 and is currently working on creating ratings for the following groups of attachment products:

- Applied Films

- Awnings

- Dynamic Attachments for Swinging Doors

- Exterior Attachments

- Interior Attachments

- Storm Doors

- Storm Windows.

\subsubsection{Timeline}

The initial phase of the experiment is projected to occur during the second quarter of FY13. The Lab Homes would both have aluminum frame, double-pane clear glass windows. The initial experiment would compare the heating season performance of Low-e storm windows on the experimental home to the existing aluminum-frame, double-pane clear glass windows in the baseline home. The storm windows would then be removed to allow for appliance studies and the cooling season ducted HPWH experiment.

The second phase of the experiment would occur in late summer 2013, beginning in July 2013 and running as a series of 1- to 2-week comparisons until September 2013. The following table provides an example of how the summer series of experiments might occur.

\begin{tabular}{cccccc}
\hline Home & Baseline & Experimental & Start Date & Stop Date & $\begin{array}{c}\text { Duration } \\
\text { (days) }\end{array}$ \\
\hline Exp 1 & None & Low-e storm windows & August 15 & August 29 & 14 \\
Exp 2 & None & Shading & August 30 & September 6 & 7 \\
Exp 3 & None & Low-e film & September 7 & September 14 & 7 \\
Exp 4 & Polychromic film & Low-e film & September 15 & September 22 & 7 \\
\hline
\end{tabular}

At the conclusion of the experiments the windows would be removed and the original windows would be reinstalled.

\footnotetext{
${ }^{4}$ http://www.ccht-cctr.gc.ca/eng/projects/solar_shadings.html; http://www.ccht-cctr.gc.ca/eng/projects/glazing.html; http://www.ccht-cctr.gc.ca/eng/projects/reflective_shading.html; http://www.cchtcctr.gc.ca/eng/projects/blind_placement.htm; http://www.ccht-cctr.gc.ca/eng/projects/blind_control.html.

${ }_{6}^{5} \mathrm{http} / / / \mathrm{www} 1$. eere.energy.gov/buildings/windowsvolumepurchase/storms.html

${ }^{6}$ http://www.iwfa.com/ConsumerInfo/CAEnergySavingsStudy.aspx
} 


\subsubsection{Potential Contributors and Collaborators}

Potential funders and interested parties include the following:

- DOE BTP-BA

- DOE BTP-Windows R\&D

- BPA

- NEEA

- Pella Windows - provide window film product for testing

- Larson Windows - provide Low-e storm windows for testing

- Lawrence Berkeley National Laboratory - technical contributor/peer reviewer.

Key PNNL staff would include Terry Mapes, project manager for DOE's High-Performance Windows Volume Purchase Program ${ }^{7}$ and for a new program aimed at encouraging the deployment of Low-E storm windows nationally.

\subsection{Non-Intrusive Load Monitoring}

\subsubsection{Project Summary}

There is significant interest from utilities and energy-metering companies (Honeywell, for example) in developing robust, reliable, and inexpensive methods of measuring disaggregated energy consumption non-intrusively and thus at lower cost than today's end-use metering strategies. Typically, NILM occurs outside the service panel and relies on learned electronic signatures to identify different appliances and loads by sensing these signals at the service entrance. However, the accuracy of this metering technique has not been verified in the field. The Lab Homes could serve as an easy and robust platform for verifying end-use disaggregation data from the NILM equipment by comparing them to the existing circuit-level measured consumption data.

\subsubsection{Timeline}

Because this experiment would not interfere with the other seasonal experiments that determine energy savings, the NILM experiment could occur at any time. The NILM equipment would be installed in April 2013 and data collection and analysis would occur, for this purpose, until June 2013.

\subsubsection{Potential Contributors and Collaborators}

Potential funders and interested parties include the entities listed in Table 7.

\footnotetext{
${ }^{7}$ http://www1.eere.energy.gov/buildings/windowsvolumepurchase/
} 
Table 6. Programs and Financial Contributions of Potential Research Partners for the NonIntrusive Load Monitoring Experiment

\begin{tabular}{lc}
\hline Entity & Roll \\
\hline DOE BTP-BA & \$- primary funder \\
DOE BTP Emerging Technologies - Sensors and & \$- primary funder \\
Controls Initiative & \\
NEEA & \$-primary funder \\
\hline
\end{tabular}




\subsection{FY14 Ideas}

This section describes experiments which are proposed to occur in FY14. These include investigation of the effectiveness of ventilation strategies typically implemented in HUD-code manufactured housing, explorations of the energy, evaluation of the energy savings and indoor air quality effects of variable speed HPs; determination of the performance of integrated water and space heating mini-split systems; and characterization of the energy savings potential of a SSL package for interior and exterior fixtures. The following table provides a schedule of the experiments proposed to occur into FY14.

Table 7. Proposed Experimental Schedule for FY14

\begin{tabular}{|c|c|c|c|c|c|c|c|c|c|c|c|c|}
\hline Month & Oct-13 & Nov-13 & Dec-13 & Jan-14 & Feb-14 & Mar-14 & Apr-14 & May-14 & Jun-14 & Jul-14 & Aug-14 & Sep-14 \\
\hline \multicolumn{13}{|c|}{ MH Ventilation } \\
\hline \multicolumn{13}{|c|}{ Variable Speed HP } \\
\hline \multicolumn{13}{|c|}{$\begin{array}{l}\text { Integrated Water and Space } \\
\text { Heating Mini-split }\end{array}$} \\
\hline SSL package & & & & & & & & & & & & \\
\hline
\end{tabular}

\subsection{Manufactured Housing Ventilation Effectiveness}

\subsubsection{Project Summary}

The U.S. Department of Housing and Urban Development (HUD) is responsible for establishing ventilation requirements for manufactured housing. Recently, the effectiveness of the existing requirements for manufactured housing has been brought into question. ${ }^{8}$ Because of this, there may be interest in exploring effective, whole-house ventilation strategies for manufactured housing. Given the concentration of manufacturers of energy-efficient manufactured homes in the Pacific Northwest, and the presence of NEEM, it makes sense that PNNL's Lab Homes would serve as the platform for such testing.

\subsubsection{Timeline}

If pursued, this research could be conducted in October and November 2013, because it does not require specific heating or cooling season data. Actually, shoulder season (the period of time between the highest and lowest temperature differentials, namely spring and fall) data would be very important for such a study, because this is often the time of lowest ventilation related to heating and cooling system operation.

\subsubsection{Potential Contributors and Collaborators}

Potential funders and interested parties include the entities listed in Table 5.

\footnotetext{
${ }^{8}$ Lubliner M, D Stevens, and B Davis. 1997. "Mechanical Ventilation in HUD-Code Manufactured Housing in the Pacific Northwest." ASHRAE Transactions. Vol. 103, Part 1, pp. 731-744. American Society of Heating,

Refrigerating and Air-Conditioning Engineers, Inc. Atlanta, Georgia.

Nabinger S, and A Persily. 2011. Impacts of airtightening retrofits on ventilation rates and energy consumption in a manufactured home. Energy and Buildings 43, no. 11: 3059-3067.

http://linkinghub.elsevier.com/retrieve/pii/S037877881100332X.
} 
Table 8. Programs and Financial Contributions of Potential Research Partners for the Manufactured Housing Ventilation Effectiveness Experiment

\begin{tabular}{ll}
\hline Entity & Roll \\
\hline HUD & \$ - primary funder \\
NEEM & \$ - potential funding \\
WSU-Extension Energy Program & Primary subcontractor (Lubliner) \\
NIST (National Institute of & Technical contributors/peer reviewers \\
Science \& Technology) & \\
NEW & Technical contributors/subcontractor \\
\hline
\end{tabular}

Within PNNL, sulfur hexafluoride tracer gas analysis equipment and expertise are available to precisely document air change rates and ventilation distribution effects.

\subsection{Variable Speed Heat Pumps}

\subsubsection{Project Summary}

During the stakeholder workshop after the Lab Homes ribbon-cutting ceremony and in subsequent conversations, significant interest was expressed in the performance of variable-speed, inverter-driven HPs, such as the Carrier GreenSpeed inverter-driven HP. ${ }^{9}$

Specifically, representatives from BPA showed interest in understanding the energy savings attributed to these devices, as well as their impact on ventilation and air distribution.

\subsubsection{Timeline}

This research is proposed to occur beginning in the fall of FY14. The experiment would proceed from December 2013 to January 2014. The cooling season data would be collected in June and July 2014.

\subsubsection{Contributors and Collaborators}

Potential funders and interested parties include the following:

- DOE BTP-BA

- BPA

- NEEA.

\footnotetext{
${ }^{9}$ http://www.residential.carrier.com/products/acheatpumps/heatpumps/infinitygs.shtml
} 


\subsection{Integrated Water and Space Heating Mini-Split Heat Pumps}

\subsubsection{Project Summary}

Forty-eight percent of homes in the United States rely on electric water heating. ${ }^{10}$ Replacing these systems with HPs has been shown to be an effective method of reducing energy consumption by as much as 62 percent. ${ }^{11}$ The water-heating HPs currently on the market provide a cooling effect in the conditioned spaces where they are located. For heating-dominated climates this effect must be made up by the space-heating system. In all-electric homes, these systems may be resistant heaters that are expensive to operate.

Mini-split HPs have proven to be effective at heating and cooling indoor air in most climates, including the cold climate where outside temperatures are as low as $10^{\circ} \mathrm{F}$ or lower. The fact that these systems do not require ducts make them excellent candidates for energy upgrades in all-electric manufactured homes and other existing houses. These systems do not inadvertently cool indoor conditioned air.

This experiment will measure the operating effectiveness of replacing conventional resistance electric space and water heating with a hybrid mini-split HP that provides indoor components for space heating and cooling and water heating. Combining the systems has the potential to greatly reduce installation costs relative to the cost of installing two separate space and hot water heating systems. Also, these systems may prove to be cost effective solutions for high-performance homes with very low space conditioning loads.

\subsubsection{Timeline}

This research is proposed to occur beginning during the winter of FY14. The experiment would proceed from February 2014 to April 2014 to characterize heating season performance. The cooling season data would be collected from July through August 2014.

\subsubsection{Potential Contributors and Collaborators}

The primary potential funder for this experiment is expected to be DOE BTP-BA.

\subsection{Solid-State Lighting Retrofit Package}

\subsubsection{Project Summary}

The Lab Homes are currently equipped with mixed incandescent and compact fluorescent lighting. SSL has been shown to have significantly improved efficiency and thermal performance, in addition to longer life. This experiment would measure energy consumption and interior temperatures of a complete

\footnotetext{
${ }^{10}$ KEMA, Inc. 2006. "Residential Water Heater Market.” Northwest Energy Efficiency Alliance. Portland, Oregon. Available at: http://www.cee1.org/eval/db_pdf/442.pdf

${ }^{11}$ Calculation based on EF of 2.4 for HPWH, EF of 1.0 of electric water heaters, and a load profile as described by the DOE test procedure for residential water heaters.
} 
SSL retrofit package in the experimental home compared to the mixed incandescent and fluorescent usage typical of most existing homes. The SSL retrofit may include interior and/or exterior fixtures.

\subsubsection{Timeline}

This research would occur in the shoulder season in FY14, from March 2014 until May 2014 when exterior foam installation in the cooling season experiments would begin. This time period would allow for good characterization of energy consumption and lighting performance, including lighting levels and interior temperatures. The SSL retrofit package would also be evaluated briefly in the beginning of September to capture the impact of reduced heating loads from lighting on extreme cooling days.

\subsubsection{Potential Contributors and Collaborators}

Potential funders and interested parties include the following:

- DOE BTP-BA

- BPA

- NEEA. 


\subsection{FY15 and Beyond}

This section describes experiments which are proposed to occur in FY15 or future years. These include investigation of the performance of $4^{\text {th }}$ generation ground source heat pumps; characterization of the thermal and air leakage properties of retrofit PCM insulation; and quantification of the load balancing characteristics of a suite of smart-grid enabled appliances interacting with a smart EV charging station and roof-top photovoltaic (PV) panels. The following table provides a schedule of the experiments proposed to occur in FY15. Future experiments could include effective strategies for implementing higher levels of exterior foam insulation.

Table 9. Proposed Experimental Schedule for FY 15

\begin{tabular}{|l|l|l|l|l|l|l|l|l|l|l|l|l|}
\hline Month & Oct-14 & Nov-14 & Dec-14 & Jan-15 & Feb-15 & Mar-15 & Apr-15 & May-15 & Jun-15 & Jul-15 & Aug-15 & Sep-15 \\
\hline Grid-Friendly Appliances & & & & & & & & & & & & \\
\hline 4th Gen GSHP & & & & & & & & & & & & \\
\hline PCM/insulation installation & & & & & & & & & & & & \\
\hline Exterior foam >1" & & & & & & & & & & & \\
\hline
\end{tabular}

\subsection{PV Interaction with Smart-Grid Enabled Appliances and EV Charging}

\subsubsection{Project Summary}

In addition to load balancing by reducing peak loads, EV charging and smart-grid enabled appliances have long been touted as large-scale energy storage solutions to allow for increased renewable energy sources (in this case PV) penetration on the grid. However, the interaction of renewable energy sources, EV charging, and smart-grid enabled appliances has not been verified. This experiment would quantify the magnitude of storage available for renewable energies (PV) from the appliances and an EV charging station in the experimental home. The research would also examine how smart charging and smart appliances can increase the number of net zero-energy homes by decreasing the dynamic impacts on the grid.

\subsubsection{Timeline}

This research would occur in the end of FY14 and FY15 and capture both low and high periods of solar insolation (proposed from September to November 2015).

\subsubsection{Contributors and Collaborators}

Potential funders and interested parties include the following:

- DOE BTP-BA

- DOE OE

- GE Appliances.

- PV Panel Manufacturers 
- Honeywell

- City of Richland.

\subsection{PCMs and Insulation Installation Best Practices}

\subsubsection{Project Summary}

Currently, the Lab Homes have 2x6 walls containing R-11 batts (pre-cut panels of insulation) that have slumped somewhat during transport and siting of the homes. In this experiment, the baseline home would be retrofit with blown-in cellulose insulation to document best practices related to insulating poorly or partially insulated wall cavities. The thermal resistance of the retrofit baseline wall would be compared to the unretrofitted walls of the experimental home, as would the impact on energy consumption. Then, the experimental home would be retrofit with PCM insulation in the wall cavity using similar techniques. This would allow for the quantification of energy savings resulting from the insulation and thermal storage properties of PCMs. This experiment will draw from and build upon research conducted by Oak Ridge National Laboratory examining PCMs in the ZEBRAlliance Homes. ${ }^{12}$

\subsubsection{Timeline}

This research is proposed to occur beginning in the winter of FY15. The experiment would run from December 2014 to January 2015 to characterize the heating season performance. The cooling season data would be collected from June through July 2015.

\subsubsection{Contributors and Collaborators}

Potential funders and interested parties include the following:

- DOE BTP-BA

- DOE BTP-Envelope R\&D

- Advanced Fiber Technology

- Cellulose Insulation Manufacturers Association

- Composite Materials and Engineering Center at WSU

- BPA

- NEEA

- City of Richland.

\footnotetext{
${ }^{12}$ http://www.zebralliance.org/
} 


\subsection{Fourth-Generation Ground-Source Heat Pump}

\subsubsection{Project Summary}

Manufacturers are currently developing a new generation of ground-source heat pumps (GSHPs) and installation (retrofit) strategies that will significantly improve their performance and applicability to various climates, as well as reduce the cost of retrofits. However, these technologies will need robust field testing prior to widespread acceptability in the retrofit residential industry. The Lab Homes present a unique platform for evaluating the installation and performance of the fourth-generation GSHPs in a very controlled environment that allows for robust diagnostics and does not inconvenience homeowners.

\subsubsection{Timeline}

The GSHP experiment is currently scheduled to occur in FY15 during winter (February through April 2015) and summer (July through September 2015) periods. Depending upon the state of the technology, joint funding, and/or interest by the industry, this experiment could be accelerated or pursued in lieu of another previously scheduled HVAC experiment.

\subsubsection{Contributors and Collaborators}

For the initial GSHP experiments, funders and interested parties include the following:

- DOE BTP-BA

- BPA

- Maul Energy Advisors (Davis, CA)

- Geothermal Heat Pump Consortium/GeoExchange.

\subsection{Exterior $>1-i n$. Insulation}

\subsubsection{Project Summary}

A current barrier to installation of high R-value exterior insulation retrofits is the siding manufacturer's warranty that limits the length a nail can cantilever between the stud and siding. Thus, battens must to be applied outside the foam for installations of higher thickness. For example, HardiPlank ${ }^{\circledR}$ can only be applied over up to 1 in. of foam, because higher levels of foam would void the warranty. This warranty issue applies to any siding applied over the insulation. ${ }^{13}$ This warranty limitation is the result of siding manufacturers having concerns about the structural integrity of the wall assembly when exterior foam insulation depths are greater than 1 in. The Lab Homes, being unoccupied, provide a low-risk opportunity to examine the structural integrity of more advanced levels of exterior insulation and perhaps develop new reinforcing techniques that allow more than $1 \mathrm{in}$. of exterior insulation to be applied cost-effectively.

\footnotetext{
${ }^{13}$ Salzberg E, M Lubliner M, A Gordon A, and K Eklund K. 2012. "Technical Solutions for High Performance Habitat Homes in Washington State." Washington State Energy Extension Program. Olympia, Washington.
} 
All manufactured housing in the United States is built to at least minimum HUD-code standards, which require $2 \times 4$ stud wall construction with R-11 insulation. Exterior foam may prove to be a package applicable to manufactured housing across the nation for achieving or exceeding these requirements costeffectively.

\subsubsection{Timeline}

This project will begin in late FY15 or early FY16 with characterization of the cooling season performance of the exterior foam retrofit, and it will continue into the winter of FY16. In September 2015, the experimental home would be retrofit with exterior foam insulation to explore cost-effective installation techniques for higher levels of insulation. A comparison of the baseline wall and the retrofit experimental wall thermal performance and energy consumption impacts in the cooling season would occur in September 2015, if weather is still appropriate. The impact of the exterior foam insulation during the heating season would be examined in the winter of FY16. With the installation of PCM insulation in FY15, the data for this technology would be characterized based on a departure from the verified difference between the Lab Homes resulting from the PCM insulation retrofit. It is expected that some accuracy would be lost as a result of this multi-experiment layering, but the data would still be accurate and reliable enough to provide good insights into the feasibility and energy performance of this exterior foam retrofit approach. Alternatively, both homes could receive the PCM insulation retrofit or the homes could be returned to their original condition. However, either of these approaches would add significant expense to the project.

\subsubsection{Potential Contributors and Collaborators}

Potential funders and interested parties include the following:

- DOE BTP-BA

- BPA

- NEEA

- WSU - Composite Materials and Engineering Center. 


\subsection{Additional Funding Needs}

While the project funds are generally adequate to conduct the Lab Homes experiments, some items require funding support (either from PNNL or from funding partners) if the Lab Homes are to remain operational and ultimately become a high-profile research platform. The expenses below should be considered when proposing budgets for Lab Home projects. These expenses may be provided by internal PNNL funding, if available.

\begin{tabular}{ll}
\hline Expenses & Approximate Cost \\
\hline Visitor Center/Information Kiosk & $\$ 100 \mathrm{~K}$ (variable) \\
Website/Stakeholder Awareness & $\$ 25,000$ initial development $+\$ 5,000 / \mathrm{yr}$ to maintain \\
Utilities \& Janitorial & $\$ 3,500 / \mathrm{yr}$ (variable) \\
\hline
\end{tabular}

\subsection{Visitor Center/Information Kiosk}

Because the Lab Homes are located on the outer boundary of the PNNL campus and have controlled access (so the experiments are not disturbed), a Lab Home center for hosting visitors and communicating information about the status and importance of the Lab Homes research is important for promoting this and other building science projects at PNNL. This visitor center has been proposed for installation in the lobby of a larger PNNL office building (Environmental Technology Building), but it could also be part of a larger buildings science information center or laboratory space. Its purpose would be to explain to visitors/potential clients the goals of the Lab Homes and the current experiment(s) via permanent displays and an interactive web-interface. Real-time data could be displayed as part of this exhibit.

The budget for a Lab Homes information center is variable based on the purpose and scale of such a facility and on available funds. The required funds range from $\$ 10 \mathrm{~K}$ for a small exhibit as part of an existing lobby display or laboratory space to $\$ 100 \mathrm{~K}$ for a coordinated buildings science information center that would give Lab Homes and other PNNL building science programs higher visibility and autonomy.

\subsection{Website}

An informative, interactive, and engaging website would create interest and publicity for the Lab Homes, while sharing data, research, and results with other researchers, future funders, and the public; ensuring the research is impactful and available. Website contents and features would include the following:

- About Lab Homes

- Baseline Home

- Experimental Home

- Tour the Homes

- Experiments

- Published Reports 
- Lessons Learned

○ Tips for Homeowners

- Builders Corner

- Focus on Health and Safety

- External Links

- Real-Time Data

- What's New

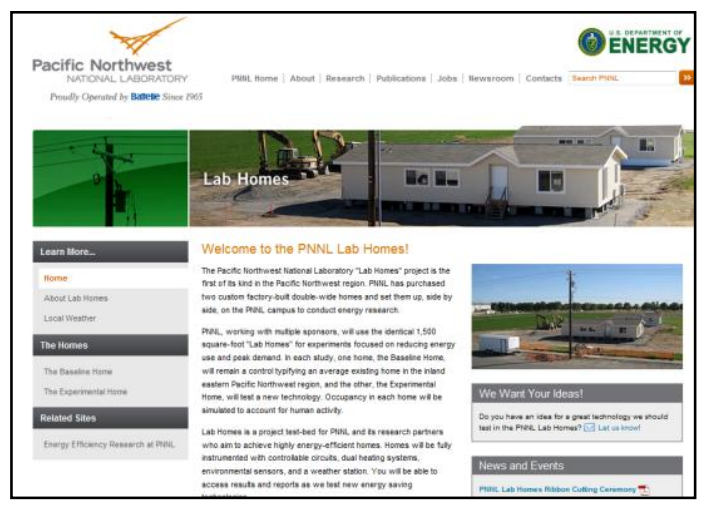

- FAQs

- Lab Homes News Feed

- Local Weather

- Contacts.

It is anticipated that such a website would cost $\$ 25,000$ to initially set up and $\$ 5,000 / y$ r to maintain and update in future years.

\subsection{Utilities and Janitorial Service}

The electric, water, and sewer bills for FY12 are being paid by the DOE BA program. In future years, each experiment conducted in the Lab Homes would need to cover these costs. These utility costs will be primarily for electricity and could be substantial (even at the low rate paid by PNNL) for any experiments involving electric vehicle charging. Utility costs are estimated to be $\$ 3,000 / \mathrm{yr}$.

Janitorial needs are minimal because the homes would not be occupied for most of the period of an experiment. The PNNL Facilities and Operations organization will provide grounds service and maintain the grass around the homes. The planting of vegetation for aesthetic improvement of the site has not been proposed. Once-a-year pest control is included with the grounds service. Thus, the anticipated budget for janitorial services is quite small, approximately $\$ 500 / \mathrm{yr}$. 


\section{Appendix A}

\section{PNNL Lab Homes Stakeholder Workshop Notes}




\section{Appendix A}

\section{PNNL Lab Homes Stakeholder Workshop Notes}

November 15, $2011(1 \mathrm{pm}-4 \mathrm{pm})$

Columbia River Room, Pacific Northwest National Laboratory Campus

Richland, Washington

\section{A.1 Attendees}

\begin{tabular}{ll}
\hline Attendees Name & Affiliation \\
\hline Michael Baechler & PNNL Program Manager \\
Kacie Bedney & BPA Program Manager \\
Jeremy Blanchard & PNNL Engineer \\
Jack Callahan & BPA Program Manager \\
Subrato Chandra, principal investigator, Lab Homes & PNNL, Senior Engineer \\
Karrie Cobb & BPA Public Utilities Specialist \\
Sandi Edgemon & City of Richland Manager \\
Ken Eklund & WSU-Extension Energy Program Team Leader \\
Tom Hughes & NW Energy Works, President \\
Mark Johnson & BPA Program Manager \\
Vrushali Mendon & PNNL Engineer \\
Dave Najewicz & GE Appliances Manager \\
Graham Parker, Project Manager, Lab Homes & PNNL Senior Engineer \\
Brady Peeks & NW Energy Works, Principal \\
Rick Pratt & PNNL Engineer \\
Susan Sande & PNNL Specialist \\
Paul Sklar & Energy Trust of Oregon \\
Clint Whitney & City of Richland, Electrical Engineer \\
Geoff Wickes & NEEA Manager \\
Sarah Widder & PNNL, Engineer \\
\hline
\end{tabular}

\section{A.2 Objective:}

A brainstorming session was conducted to identify research topics and experiment ideas for the Lab Homes. (Facilitated by Michael Baechler, notes by Sarah Widder and Susan Sande.)

After the discussion, participants voted on the research topics of most interest to them or their agency. Each participant got six votes.

Legend: $\sqrt{ } \#=$ total number of votes $($ green $=$ PNNL, red $=$ non-PNNL) 


\section{A.3 Parking Lot}

\section{How will publishing work?}

- Reports will be posted on the website: labhomes.pnnl.gov

- Real-time data?

- Other resources?

- Online parking lot for further discussion?

- Conduit

\section{How do we prioritize experiments?}

- Sponsor interest

- Cost effectiveness

- Climate or regional considerations?

\section{Look at effective application methods to achieve energy efficiency?}

- E.g., Do quality assurance with an infrared gun on insulation installation

- Keep installation techniques market applicable

- e.g., T1-11 application for wall insulation retrofit

\section{Look at potential for acceptance}

- Focus on developing technologies for which people can plan their replacement (e.g., roof), not systems that must be replaced quickly in an emergency (e.g., hot-water heater)

- Long-term decision vs. new technologies

- You can anticipate and put thought into the purchase.

- Emphasize technologies that are either commercially available or nearing that stage $\sqrt{ }$

\section{How to achieve deployment?}

- Collaborate with technicians/trades

- Note that the president of the Tri Cities Home Builders Association was at the ribbon-cutting ceremony and expressed an interest in our testing results...could be an ally here.

- Bring in trades to problem solve with you.

\section{How long do you have to take data for a good measurement?}

- Two weeks 
Bike rack at Lab Homes

\section{A.4 Energy-Efficient Envelope Measures}

\section{A.4.1 Short Term (market ready)}

\section{Insulation}

- Interior vs. exterior

- Cavity

- Fill different bays with different types of loose-fill wall insulation; measure temperature gradients

- Performance of dense packing wall insulation

- Attic

- How do you achieve full insulation value at the eaves?

- Insulation degradation over time

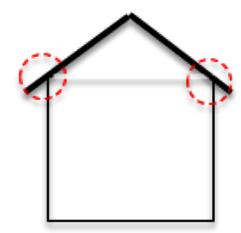

Air sealing solutions $\sqrt{ }$

- Envelope

- Ducts

- Belly of modular homes

\section{Exterior wall measures $\sqrt{ } 5$}

- Paint color and shading (trees or mechanical) $\sqrt{ } \sqrt{ }$

\section{Roof Measures}

- Roof materials $\sqrt{ } \sqrt{ }$

- Color of roofs/cool roofs

- Insulation on back side of roofing material or roof deck

- Portland roofers are installing polyiso sandwich insulation

- Attic venting/mechanical venting

\section{Attic Strategies}

- Vented

- Solar attic fans (mechanically vented)

- Depressurization issue

- Want to cool your house at night 
- Worthwhile?

- Versus

- Sealed attic - foam

\section{Crawlspace}

- Vented vs. sealed

- Vapor barrier

- U.S. Department of Housing and Urban Development code?

- Washington State code?

- Rigid foam underneath floor joists to seal crawlspace from conditioned space $\sqrt{3}$

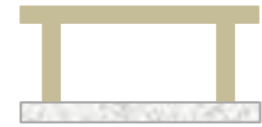

- Could apply to manufactured homes? Yes, but must be cost effective

\section{A.4.2 Long Term}

\section{Long term could be defined as:}

- not market available

- research oriented

- emerging technology

- not common practice but has potential

\section{Exterior Wall/Roof Measures}

- Phase change materials

- Building-integrated photovoltaics

- Roof integrated

- Window integrated

- Radiant paint

- Are there any other emerging technologies?

\section{A.5 Windows}

\section{First Experiment}

- R5 compared to double pane clear aluminum-framed in baseline home.

- Measure incident solar and heat gains through glass, glass temperature, moisture on glass surface (one window) 


\section{Other future experiments}

- Shading, covering

- Electrochromic/dynamic (3+ years out)

- Installation and use $\sqrt{ }$

- of windows

- of shading devices

\section{A.6 Lighting}

\section{Existing Lighting Configuration in Lab Homes}

- As installed in Lab Homes

- Ceiling fixtures - one compact fluorescent light and two fixtures with incandescent for windows experiment

- Vanity - incandescent

- No strip fluorescent

- No recessed cans

\section{Future Experiments/Technologies}

- Solid-state lighting (SSL) package or SSL/fluorescent $\sqrt{ }$

- Quality important, color, dimmability, startup time

- Look at California Title 24 for California-specific specifications.

\section{Resources/Partners}

- Lighting Research Center

- Efficiency

- Design

\section{A.7 Domestic Hot Water}

\section{Existing Lab Home Systems}

- Electric resistance water heater inside home

\section{Other Ideas}

- Heat pump water heater (HPWH)

- With ducting to outside $\sqrt{ } 4 \sqrt{ } 3$

- Interaction with heat recovery ventilator 
- Make-up air strategies $\sqrt{ } 1 \sqrt{ } 3$

- Draw air from crawlspace

- Meet NEEA Northern Tier (cold climate) specification

- Interactions between ductless heat pump (HP) and HPWH $\sqrt{3} \sqrt{8}$

- $\quad$ Air temperatures

$\circ$ Prevent freezing of pipes $\rightarrow$ alarm?

- Power

- Humidity

- Grid-friendly HPWH

- Control strategies

- Solar thermal

\section{A.8 HVAC Measures}

\section{Existing Lab Home Systems}

- Dual system: HP/furnace and wall heaters with fans (master bedroom closet space) with exterior door and insulated walls

\section{Heat Pumps}

- Ground contact/geothermal

- Verify ductless and air source can perform well at low temperatures

- Inverter ductless HPs

- Crawlspace coupled to HP

- Look at temperature/relative humidity interactions to inform choice/impact on power (see graphic)

\begin{tabular}{|c|c|}
\hline & $\begin{array}{l}\text { Installation Strategy (buffered } \\
\text { space, inside, outside) }\end{array}$ \\
\hline 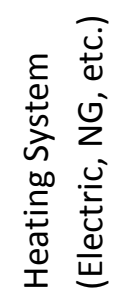 & $\begin{array}{c}\text { Characterize energy } \\
\text { consumption, impact on } \\
\text { interior temp/RH distributions }\end{array}$ \\
\hline
\end{tabular}

- Forced-air furnace as distribution system for ductless $\sqrt{ } 2 \sqrt{6}$

- Control strategies/thermostats between ductless and other heating systems $\sqrt{ } 3$

- Fan energy use

- How does changes in fan speed/variable speed fan affect thermal performance and mixing? $\sqrt{ } 1 \sqrt{ } 2$

- Do we need to simulate gas?

- Electronically commutated motors

- Constant torque motors 


\section{Ducts}

- Zonal dampers, occupancy sensors (key), and potential for control strategies and learning.

- Mountain Logic or other Emerging Technology group

- How to simulate occupancy? $\sqrt{ }$

- Test data exits with bladders

\section{Cooling $\sqrt{ }$}

- Evaporative pre-cooling $\sqrt{ }$

- In Sixth Power Plan?

- Source of information: University of California Davis, Western Cooling Efficiency Center

- New heat exchanger

- Economizer

- Night cooling

- Ice Bear 5 ton ice storage

- Work with Climate Solutions out of Sweden

- Solar-driven absorption chiller

- Carbon dioxide as a working fluid in Japanese HPs $\sqrt{ } 2$

\section{A.9 Appliances}

\section{Existing Lab Homes}

- Range and refrigerator in both homes.

\section{Grid-Friendly Appliances}

- Install GE grid-friendly appliances (washer, dryer, refrigerator, range, dishwasher) along with HPWH in experimental home

- Send artificial rate/price signals

- Integration with electric vehicle $(\mathrm{EV})$ charging? $\sqrt{ } \sqrt{ }$

- Reactive energy measurements $\sqrt{ } 2$

- Important to characterize reactive energy and energy savings

- What do outage events and re-energization look like?

- Home energy management systems

- PV integration with grid-friendly appliances $\sqrt{ } \sqrt{ }$

- Smart inverters also 
- Plug loads $\sqrt{ } 2 \sqrt{ }$

- Simulated by light bulbs or hot plates

○ $15 \mathrm{kWh} /$ day

- distribute spatially and temporally

- BA schedule

- Interactive effect of higher-efficiency appliances/miscellaneous electric loads with heating/cooling loads

\section{A.10 Electric Vehicle Charging}

- Load on outside of structures

- Data on driving and charging behavior $\sqrt{ } \sqrt{ }$

- With Nissan Leafs $\rightarrow$ City of Seattle project

- All cars are set to start charging at 12 am

- Potential to spread out charging load

- Interaction between EV $\leftrightarrow$ Home Area Network $\leftrightarrow \rightarrow$ Utility

- Needs $\sqrt{ }$

- Two charging stations

- Grid-friendly charging dock inside

- Charging station outside

- Communication protocol

○ Needs standardization

- Will EV-charging experiment affect the windows experiment?

- Comparison to electric bike load profile and energy consumption

\section{A.11 Metering $\sqrt{ } 3 \sqrt{ }$}

- Evaluate non-intrusive metering techniques

- Thermostat/metering device (Plot Watt) $\sqrt{ } 3$

○ Monitor appliances, power usage based on voltage and current measurements

- Short-term measurements to predict annual performance? $\sqrt{2}$

\section{A.12 Renewable Energy}

- Rooftop PV (with our without storage?) 


\section{A.13 Possible Funding Sources}

BPA technology/R\&D type projects

- Submit by March 2012, award July 2012, start September 2012

- Gaps in technology roadmaps

BPA technology innovation/emerging technologies FY13

- No outside proposals

- Promising technology statement of work is funded

- No particular schedule

NEEA unsolicited proposals for promising technologies

- All year

- $\mathrm{FY}=\mathrm{CY}$

- Can be collaborative

- Connection to NEEA residential stock assessment, possible synergies

\section{Energy Trust of Oregon Utilities}

- All four

- $\mathrm{FY}=\mathrm{CY}$

- Budget planning in August

\section{City of Richland}

- $\mathrm{FY}=\mathrm{CY}$

- Start planning mid-year 


\section{Appendix B}

\section{Proposed Experimental Schedule for the PNNL Lab Homes}




\section{Appendix B}

Gantt Chart of Proposed Experimental Schedule

\begin{tabular}{|c|c|c|c|c|c|c|c|c|c|c|c|c|}
\hline Month & Oct-11 & Nov-11 & Dec-11 & Jan-12 & Feb-12 & Mar-12 & Apr-12 & May-12 & Jun-12 & Jul-12 & Aug-12 & Sep-12 \\
\hline \multicolumn{13}{|l|}{ Ribbon Cutting } \\
\hline \multicolumn{13}{|l|}{ Meter Installation } \\
\hline \multicolumn{13}{|l|}{ Null Testing } \\
\hline \multicolumn{13}{|l|}{ R-5 Windows } \\
\hline Smart-Grid Enabled Appliances & & & & & & & & & & & & \\
\hline
\end{tabular}

FY 13

\begin{tabular}{|c|c|c|c|c|c|c|c|c|c|c|c|c|}
\hline Month & Oct-12 & Nov-12 & Dec-12 & Jan-13 & Feb-13 & Mar-13 & Apr-13 & May-13 & Jun-13 & Jul-13 & Aug-13 & Sep-13 \\
\hline \multicolumn{13}{|c|}{ Smart-Grid Enabled Appliances } \\
\hline \multicolumn{13}{|c|}{ Ducted HPWH } \\
\hline \multicolumn{13}{|c|}{ Low-E Storm Windows } \\
\hline NILM & & & & & & & & & & & & \\
\hline
\end{tabular}

FY 14

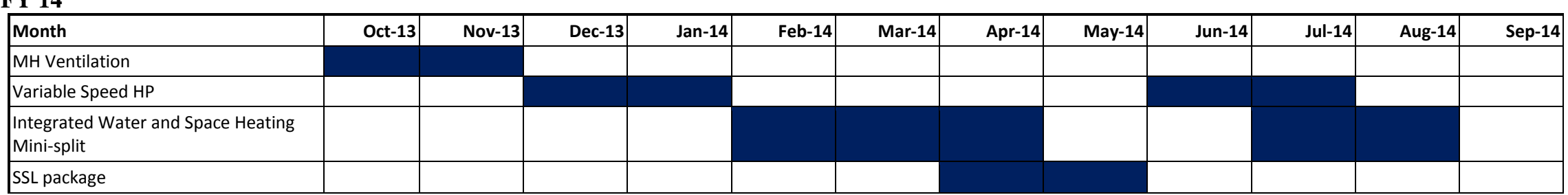

FY 15

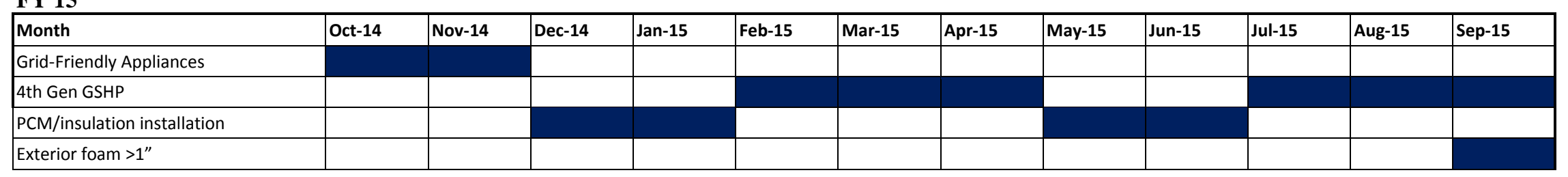





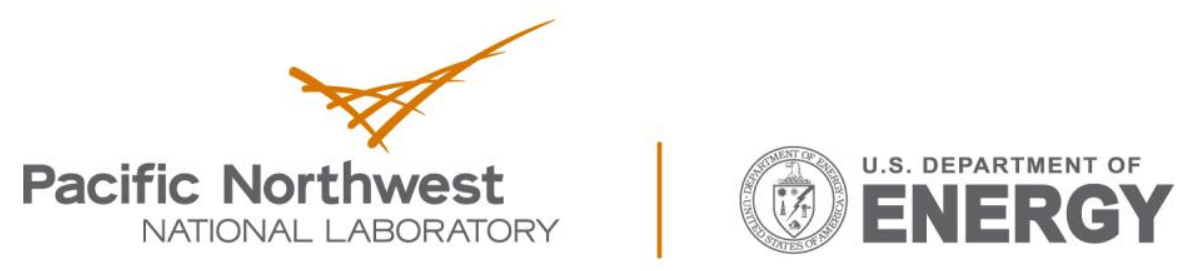

Proudly Operated by Battelle Since 1965

902 Battelle Boulevard

P.O. Box 999

Richland, WA 99352

1-888-375-PNNL (7665)

www.pnnl.gov 